\title{
PROFIL PENDERITA OSTEOARTRITIS LUTUT DENGAN OBESITAS DI INSTALASI REHABILITASI MEDIK BLU RSUP PROF. DR. R. D KANDOU MANADO
}

\author{
${ }^{1}$ William Kusuma \\ ${ }^{2}$ Engeline Angliadi \\ ${ }^{2}$ L. S. Angliadi \\ ${ }^{1}$ Kandidat Skripsi Fakultas Kedokteran Universitas Sam Ratulangi Manado \\ ${ }^{2}$ Bagian Rehabilitasi Medik Fakultas Kedokteran Universitas Sam Ratulangi Manado \\ Email: kusumawilliam@yahoo.com
}

\begin{abstract}
: osteoarthritis is derived from greek meaning bone, arthro meaning joint and itis meaning inflammation. Osteoarthritis is a degenerative joint disease that is chronic,progessive runing slow, often inflamed or causes only mild inflammation, and characterized by deterioration and abrasion of articular cartilage as well as by two risk factor are: risk factors that cannot be changed and modifable risk factors. Obesity is a global epidemic in developed countries and developing countries such as Indonesia, particularly in urban strip. This situation is caused by unbalanced energy intake with energy expenditure and excess energy is stored as body fat within a specified period. Objectives: this study aimed to determine the role of risk factor of obesity on the incidence of osteoarthitis of the knee in patients who visit the Rehabilitation Medical Installation BLU Prof. DR. R. D. Kandou Manado. Method: this type of research is descriptive research by taking medical record in medical rehabillitation installation at BLU RSUP Prof. DR. R. D. Kandou Manado. Result: in this study was obtained from descriptive data/medical record(MR) found the number of patients diagnosed with osteoarthritis of the knee by 74 people. Obtained as many as 31 people who have data(weight and height),3 complete lack data because just have weight and 40 people don't have either weight or height. Research results knee OA patient who come control in the installation of medical rehabillitation only 31are listed the data Body Mass Indeks(weight and height), there are 5 people who have normal BMI, and 26 people who had a BMI of both overweight and obesity excess. Conclusion: from here we may see one of the risk factor for OA knee is obesity
\end{abstract}

Keywords: Knee osteoarthritis, obesity.

\begin{abstract}
Abstrak: Osteoartritis (OA) berasal dari bahasa Yunani yaitu osteo yang berarti tulang, arthro yang berarti sendi dan itis yang berarti inflamasi. Osteoartritis adalah penyakit degeneratif sendi yang bersifat kronik, berjalan progresif lambat, seringkali tidak meradang atau hanya menyebabkan inflamasi ringan, dan ditandai dengan adanya deteriorasi dan abrasi rawan sendi serta oleh 2 faktor resiko yaitu: faktor resiko yang tidak dapat diubah dan faktor resiko yang dapat diubah. Obesitas merupakan epidemi global pada negara-negara maju dan negara berkembang seperti di Indonesia, terutama di daerah perkotaan. Keadaan ini diakibatkan karena pemasukan energi tidak seimbang dengan pengeluaran energi dan kelebihan energi ini disimpan dalam bentuk lemak tubuh dalam jangka waktu tertentu. Tujuan: Penelitian ini bertujuan untuk mengetahui peranan faktor resiko obesitas terhadap angka kejadian osteoartritis lutut pada penderita yang berkunjung di Instalasi Rehabilitasi Medik BLU RSUP Prof. DR. R. D. Kandou Manado. Metode: Jenis penelitian ini adalah penelitian deskriptif dengan mengambil data rekam medik di Instalasi Rehabilitasi Medik BLU RSUP Prof. DR. R. D. Kandou Manado. Hasil: Pada penelitian yang didapatkan dari data deskriptif/rekam medik (RM) didapatkan jumlah penderita yang didiagnosis dengan osteoartritis lutut sebanyak 74 orang. Didapatkan sebanyak 31 orang yang memiliki data BB dan TB, 3 data kurang lengkap yaitu hanya terdapat data BB dan 40 data yang tidak mempunyai baik BB maupun TB. Hasil penelitian
\end{abstract}


menyatakan penderita OA lutut yang datang kontrol di Instalasi Rehabilitasi Medik,hanya 31 yang tercantum data IMT (BB\&TB),terdapat 5 orang yang memiliki IMT normal,dan 26 orang yang memiliki IMT berlebih baik overweight maupun obesitas. Simpulan: Dari sini kita bisa melihat salah satu faktor resiko OA lutut adalah obesitas.

Kata Kunci: Osteoartritis lutut, Obesitas.

Osteoartritis (OA) berasal dari bahasa Yunani yaitu osteo yang berarti tulang, arthro yang berarti sendi dan itis yang berarti inflamasi. Osteoartritis adalah penyakit degeneratif sendi yang bersifat kronik, berjalan progresif lambat, seringkali tidak meradang atau hanya menyebabkan inflamasi ringan, dan ditandai dengan adanya deteriorasi dan abrasi rawan sendi serta oleh 2 faktor resiko yaitu: faktor resiko yang tidak dapat diubah yakni faktor genetik, jenis kelamin, suku/ras dan usia. Sedangkan faktor resiko yang dapat diubah yakni obesitas, hormonal, aktivitas fisik berlebihan, kelemahan otot dan trauma/cedera. ${ }^{1}$

Obesitas merupakan epidemi global pada negara-negara maju dan negara berkembang seperti di Indonesia, terutama di daerah perkotaan. Keadaan ini diakibatkan karena pemasukan energi tidak seimbang dengan pengeluaran energi dan kelebihan energi ini disimpan dalam bentuk lemak tubuh dalam jangka waktu tertentu ${ }^{1}$.

Pada tahun 1998 WHO menyatakan adanya epidemik global dari obesitas. Bukan hanya pada negara maju adanya peningkatan prevalensi obesitas tapi juga pada negaranegara berkembang. Perkembangan teknologi yang sangat memberikan kemudahan yang berdampak pada berkurangnya aktifitas fisik sehingga mengurangi pengeluaran energi. Selain itu budaya makanan cepat saji gaya barat merubah pola makan lokal., ${ }^{1,2}$

\section{METODE}

Penelitian ini merupakan penelitian deskriptif. Sumber data di ambil dari data sekunder rekam medik Instalasi Rehabilitasi Medik di BLU RSUP Prof. Dr. R. D. Kandou Manado. Penelitian di laksanakan di Instalasi Rehabilitasi Medik BLU RSUP
Prof. Dr. R. D. Kandou Manado. Waktu penelitian Januari-Februari 2014. Populasi dan Sampel: populasi yang diambil adalah pasien yang terdiagnosis osteoartritis di dalam rekam medik, sampel yang diambil adalah total populasi yang memenuhi kriteria inklusi dan eksklusi, cara pengambilan sampel adalah data sekunder yang didapat dari rekam medik Instalasi Rehabilitasi Medik dari Januari-Juni 2013. Variabel penelitian yang akan diteliti adalah penderita OA lutut yang datang ke Instalasi Rehabilitasi Medik BLU RSUP Prof. Dr. R. D. Kandou Manado.,3

\section{Definisi Operasional}

- Osteoartritis merupakan penyakit sendi degeneratif yang berkaitan dengan kerusakan kartilago sendi

- Kegemukan/obesitas didefinisikan sebagai abnormal atau berlebihan akumulasi lemak yang berlebihan yang dapat mengganggu kesehatan.

- Indeks massa tubuh (IMT) merupakan indeks sederhanaberat/tinggi yang biasa digunakan untuk mengklasifikasikan kelebihan berat badan lebih/obesitas pada orang dewasa.

\section{HASIL}

Pada penelitian yang didapatkan dari data deskriptif/rekam medik (RM) didapatkan jumlah penderita yang didiagnosis dengan osteoartritis lutut sebanyak 74 orang. Didapatkan sebanyak 31 orang yang memiliki data BB dan TB, 3 data kurang lengkap yaitu hanya terdapat data $\mathrm{BB}$ dan 40 data yang tidak mempunyai baik BB maupun TB. Dari 74 orang didapatkan 25 orang laki-laki dan 49 perempuan. Melalui data rekam medis (lampiran 1) di dapatkan 5 orang normal, 8 orang overweight,10 orang obesitas I dan 8 orang obesitas II. Dari 8 orang overweight 4 orang laki-laki dan 6 
Kusuma, E Angliadi, L. S. Angliadi; Profil Penderita Osteoartritis Lutut...

orang perempuan. Dari 10 orang obesitas I,4 orang laki-laki dan 6 orang perempuan, Dari 8 orang obesitas II, 1 orang laki-laki dan 7 orang perempuan.

\section{BAHASAN}

Dari data ditemukan bahwa dari 31 data penderita yang tercantum BB dan Tbnya, dari 31 data ditemukan 5 normal,8 overweight,10 obesitas I dan 8 obesitas II dan dari hasil di atas menyatakan bahwa berat badan penderita mempunyai peran yang cukup penting dengan tingkat terjadinya osteoartritis.

\section{Distribusi Umur Penderita}

Data yang diperoleh dari 74 rekam medik memperlihatkan umur penderita berkisar antara usia 46 tahun sampai dengan 80 tahun dengan penderita terbanyak pada usia 65 tahun dan 67 tahun, serta rerata umur penderita adalah 64,97 tahun.

Dari data pada lampiran/diagram pie terlihat bahwa dari 74 penderita, 14 penderita berada pada kelompok umur 6064 tahun, 19 penderita berumur 65-69 tahun, dan sebanyak 24 penderita memiliki umur 70 tahun ke atas. Menurut Schellevis et $a l^{15}$ pada tahun 1993 satu dari lima penderita yang lebih tua dari umur 65 tahun, memiliki 1 kondisi yang sudah menahun, dan satu dari tujuh orang memiliki lebih dari satu kondisi yang menyertai. ${ }^{4}$

\section{Karakteristik Jenis Kelamin Penderita}

Dari data yang ditemukan pada rekam medik sebanyak 25 penderita berjenis kelamin laki-laki dengan jumlah sebesar $33,78 \%$ dan 49 orang wanita dengan jumlah sebesar 66,22\%.

Pada Dari data yang diperoleh, jumlah penderita perempuan yang terekam lebih banyak dari pada penderita laki-laki. Menurut studi yang dilakukan oleh Evans J, et al pada tahun 2000, rasio jenis kelamin untuk penderita yang terkena OA perempuan dibanding dengan laki-laki adalah 1,5:1 hingga 4:1. Perempuan memiliki faktor resiko terkena OA karena berhubungan dengan menopause, dan perempuan yang menjalani histerektomi juga memiliki faktor resiko mendapat O. ${ }^{4}$

\section{Data IMT penderita}

Penderita yang masuk dalam penelitian ini sebagian besar mempunyai Indeks Massa Tubuh $($ IMT) $>25,0$ yaitu sejumlah 18 orang atau 58,06\%. Hal ini

sesuai dengan penelitian Kun Salimah ${ }^{1}$ yang mengatakan bahwa seseorang dengan $I M T>22$ (overweight) mempunyai resiko terkena osteoartritis lutut 2,083 kali lebih besar dari pada seseorang dengan $I M T<22 .{ }^{1}$

Dari hasil penelitian di temukan 10 orang obesitas I dengan IMT $\geq 25-29,9$ dan 8 orang obesitas II dengan IMT $\geq 30$. Dari data ini didapatkan penderita dgn obesitas I lebih banyak dibandingkan penderita dengen obesitas II. Menurut teori, faktor resiko terjadinya OA adalah berat badan yang melebihi normal, sehingga memberi beban yang berlebihan pada lutut. Berhubung data yang ditemukan sangat kurang sehingga perlu adanya penelitian yang lebih lanjut dengan jumlah sampel yang lebih banyak.

Obesitas merupakan salah satu metabolic syndrome. Yang ditandai dengan IMT berlebih. Obesitas erat hubungannya dengan peningkatan resiko sejumlah komplikasi yang dapat terjadi sendiri-sendiri atau secara bersamaan, salah satu nya adalah OA. Menurut Coggon D, et $a l^{15}$ pada tahun 2001, terdapat $33.7 \%$ penderita obesitas dengan OA dari 729 kasus. ${ }^{4}$

Pada penelitian Framingham $\mathrm{MA}^{4}$ tahun 1991 didapatkan hubungan yang kuat antara obesitas dan OA pada perempuan. Pada penelitian Cushnagan ${ }^{4}$ tahun 1991 ternyata sebagian besar penderita OA mempunyai berat rata-rata di atas normal. Pada penelitian Health and Nutrition Examination Survey (HANES) I, ternyata didapatkan pula hubungan yang erat antara berat badan dengan OA lutut $\left(\right.$ Isbagio $^{15}$,1995). Pengaruh dari kondisi mekanik dalam hal ini adalah tingginya IMT, menjadi salah satu faktor resiko untuk terbentuknya OA lutut. Dalam penelitian Breedveld FC, 2004, menghitung dan menyimpulkan bahwa mengurangi $2 \mathrm{~kg} / \mathrm{m} 2$ saja dapat menurunkan faktor resiko 
terbentuknya OA lutut sebesar 20\% hingga $30 \%{ }^{4}$

Kegemukan yang dalam penelitian ini diwakili oleh IMT menyebabkan

stress abnormal pada sendi lutut. Stress abnormal menyebabkan terjadinya perubahan biofisika yang berupa fraktur jaringan kolagen dan degradasi proteoglikan. Adanya fraktur jaringan kolagen memungkinkan cairan sinovial mengisi celah yang terdapat pada kartilago dan membentuk kista subkondral. ${ }^{1}$

Osteofit yang terbentuk pada permukaan sendi dapat terjadi akibat proliferasi pembuluh darah di tempat rawan sendi berdegenerasi, kongesti vena yang disebabkan perubahan sinusoid sumsum yang tertekan oleh kista subkondral, atau karena rangsangan serpihan rawan sendi kemudian terjadi sinovitis sehingga tumbuh osteofit pada tepi sendi, perlekatan ligamen atau tendon dengan tulang. Dengan kata lain, osteoartritis lutut pada seseorang yang gemuk terjadi karena sebab mekanik. ${ }^{1}$ Pemikiran ini didasarkan pada hasil penelitian Kun Salimah serta Shiozaki dan kawan-kawan. Hasil penelitian longitudinal selama 14 tahun yang dilakukan oleh Shiozaki ${ }^{1}$ dan kawan-kawan mengatakan IMT yang lebih tinggi pada saat pertama kali survei meningkatkan resiko baik inisiasi maupun progresivitasdari osteoartritis lutut. Wanita obesitas (IMT $\geq 25,0)$ dengan penurunan IMT sebesar dua unit atau lebih selama 14 tahun, mempunyai resiko yang lebih rendah untuk mengalami perburukan gambaran sendi lutut secara radiologis. Meskipun demikian, penambahan berat badan tidak mengubah resiko secara signifikan. ${ }^{4}$

Berhubung data yang ada kurang lengkap, penulis kesulitan untuk melihat/menganalisa dan membuat profil penderita OA akibat faktor resiko obesitas.

\section{SIMPULAN}

Penderita OA lutut yang datang kontrol di Instalasi Rehabilitasi Medik,hanya 31 yang tercantum data IMT(BB\&TB),terdapat 5 orang yang memiliki IMT normal,dan 26 orang yang memiliki IMT berlebih baik overweight maupun obesitas. Dari sini kita bisa melihat salah satu faktor resiko OA lutut adalah obesitas.

\section{DAFTAR PUSTAKA}

1. Koentjoro Sara. Hubungan antara indeks masa tubuh (IMT) dengan derajat osteoartritis lutut menurut kellgren dan lawrence [Skripsi]. Semarang : Universitas Diponegoro; 2010

2. Wahyuningsi N. 2009. Hubungan Obesitas Dengan Osteoartritis Lutut Pada Lansia di Kelurahan Puncangsawit Kecamatan Jebres Surakarta. Surakarta: Universitas Sebelas Maret; 2009

3. Purnamawati irene. Prevalensi obesitas pada anak taman kanak-kanak di kelurahan Cikini,kecamatan Menteng, DKI Jakarta, dan faktor-faktor yang mempengaruhinya[skripsi]. Jakarta: Universitas Indonesia; 2009

4. Sunarti S, Ridwan $M$, Firdaus $M \quad M$. Komorbiditas Pasien Geriatri Dengan Osteoarthritis Genu Di Rumah Sakit Dr. Saiful Anwar Malang. Malang : Fakultas Kedokteran Universitas Brawijaya; 2011 